\title{
RADIOCARBON AND VARVE CHRONOLOGIES OF ANNUALLY LAMINATED LAKE SEDIMENTS OF GOSCIA̧Z LAKE, CENTRAL POLAND
}

\author{
TOMASZ GOSLAR, ANNA PAZDUR, MIECZYSŁAW F PAZDUR \\ and ADAM WALANUS \\ Radiocarbon Laboratory, Institute of Physics, Silesian Technical \\ University, Krzywoustego 2, PL-44-100 Gliwice, Poland
}

\begin{abstract}
A sequence of annually laminated sediments of the Gościaz Lake spans ca $13,000 \mathrm{yr}$ and is actually the longest known continuous sequence in the world. ${ }^{14} \mathrm{C}$ age measurements were performed on organic and carbonate fractions of bulk samples of laminated sediments from core G0. Accurate measurements of varve thickness performed on the lower part of cores $\mathrm{G} 1$ and $\mathrm{G} 2$ were used to establish a floating varve chronology covering ca 10,000 yr. Matching of cores $\mathrm{G} 0, \mathrm{G} 1$ and $\mathrm{G} 2$ permits comparison of ${ }^{14} \mathrm{C}$ dates with varve chronology. Good agreement of calibrated ${ }^{14} \mathrm{C}$ dates with the varve time scale suggests annual lamination of the sediment. Analysis of periodicities in varve thickness indicates solar 11-and 22-yr cycles, as well as a 200 -yr cycle over a good part of the investigated sequence. Results of ${ }^{14} \mathrm{C}$ measurements of carbonate fractions are used to study changes in the water depth of the lake during its history.
\end{abstract}

\section{INTRODUCTION}

In recent years there has been an increasing interest in annually laminated lake sediments from various parts of the world. As discussed in comprehensive reviews by O'Sullivan (1983) and Saarnisto (1986), such sediments may be used for studying various aspects of the Quaternary, including geochronology, climatic changes and the history of vegetation. The importance of laminated lake sediments and glacial varves for studies of natural ${ }^{14} \mathrm{C}$ changes was realized ca 20 years ago, and the early results of Stuiver (1970) and Tauber (1970) were recently reassessed in light of new calibration data (Stuiver et al, 1986). Important results on ${ }^{14} \mathrm{C}$ and varve chronology were also obtained from studies of laminated lake sediments of, eg, Schleinsee, Germany (Geyh, Merkt \& Müller, 1971) and Lake Lampellonjärvi, South Finland (Tolonen, 1980).

The sequence of laminated sediments of Lake Gościąz, central Poland, spanning $>12,500 \mathrm{yr}$ (Ralska-Jasiewiczowa, Wicik \& Więckowski, 1987) is actually the longest known in the world ( $c f$, Saarnisto, 1986, Table 17.1, p 344 ). It presents a unique opportunity to study environmental change during a significant part of the Late Glacial and Holocene, with potential significance for studying natural ${ }^{14} \mathrm{C}$ variations and calibration of the ${ }^{14} \mathrm{C}$ time scale beyond 10,000 BP, using AMS-dated terrestrial macrofossils. This paper presents a short summary of results of chronologic studies on cores collected in 1985 and 1987.

Cores

\section{RADIOCARBON AND VARVE CHRONOLOGY}

The chronologic studies are based on four cores (Fig 1), taken in the deepest part of the lake at water depth, ca $26 \mathrm{~m}$. Core G0 was taken in 1985 in 1m segments; cores G1, G2 and G3 were taken in 1987 in $2 \mathrm{~m}$ segments 


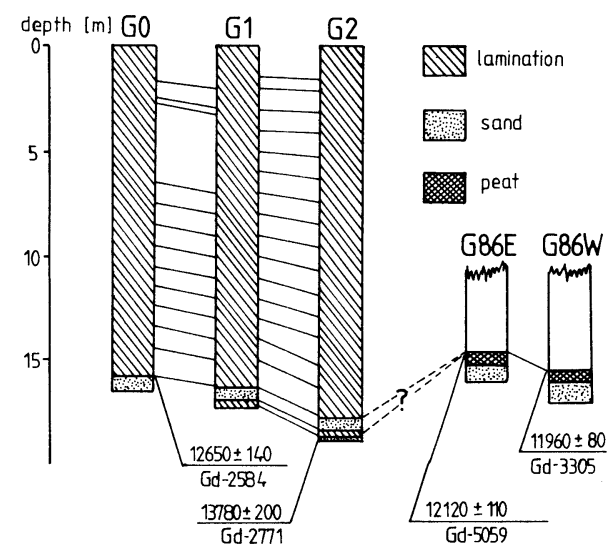

Fig 1. Correlation of cores (G0, G1 and G2 with G86E and G86W)

in approximately the same place as core G0. The distance between cores $\mathrm{G} 1, \mathrm{G} 2$ and $\mathrm{G} 3$ was ca $5 \mathrm{~m}$. All the cores have reached the sandy layer below the laminated sediment. In cores $\mathrm{G} 1$ and $\mathrm{G} 2$, a short laminated sequence (ca $30 \mathrm{~cm}$ thick) was found below a sandy layer, ca $50 \mathrm{~cm}$ thick. Corings in other parts of the lake provided two cores with thin peat layers below the lake marl; unfortunately, lamination in these cores was not visible.

\section{${ }^{14} \mathrm{C}$ dating}

${ }^{14} \mathrm{C}$ age determinations were performed on carbonate and organic fractions of bulk samples from core G0. The results are shown in Figure 2 as functions of the number of couplets in this core, estimated by $\mathrm{K}$ Więckowski ( $f$ Pazdur et al, 1987). Three characteristic features should be noted: 1$)^{14} \mathrm{C}$ dates of both organic and carbonate fractions are greater than the corresponding number of couplets, $\mathrm{N} ; 2){ }^{14} \mathrm{C}$ dates of carbonate fraction are older than those obtained on organic matter; 3 ) the difference between ${ }^{14} \mathrm{C}$ dates and the number of couplets decreases with increasing age. According to the $\delta^{13} \mathrm{C}$ values, shown in the lower part of Figure 2, the core may be regarded as isotopically bipartite. These observations lead to the conclusion that ${ }^{14} \mathrm{C}$ dates of organic matter, which show higher regularity, can be corrected for initial apparent age in the lower and upper parts of the core. Corrected conventional ${ }^{14} \mathrm{C}$ dates of organic fractions in the uppermost part of the core, obtained by subtracting a constant correction of $1600 \mathrm{yr}$, were then calibrated according to Stuiver and Pearson (1986), Pearson and Stuiver (1986) and Pearson et al (1986). A similar procedure was applied to dates from the lowermost part of the core, ie, subtracting a constant value of $1400 \mathrm{yr}$ and using the calibration curve of Stuiver et al (1986). Age correction of $1600 \mathrm{yr}$ was determined by assuming zero age of the youngest sample; the value of $1400 \mathrm{yr}$ was determined by trial and error. The calibrated ages are shown as solid squares in Figure 2. The least squares line (Fig 2) has the equation: 


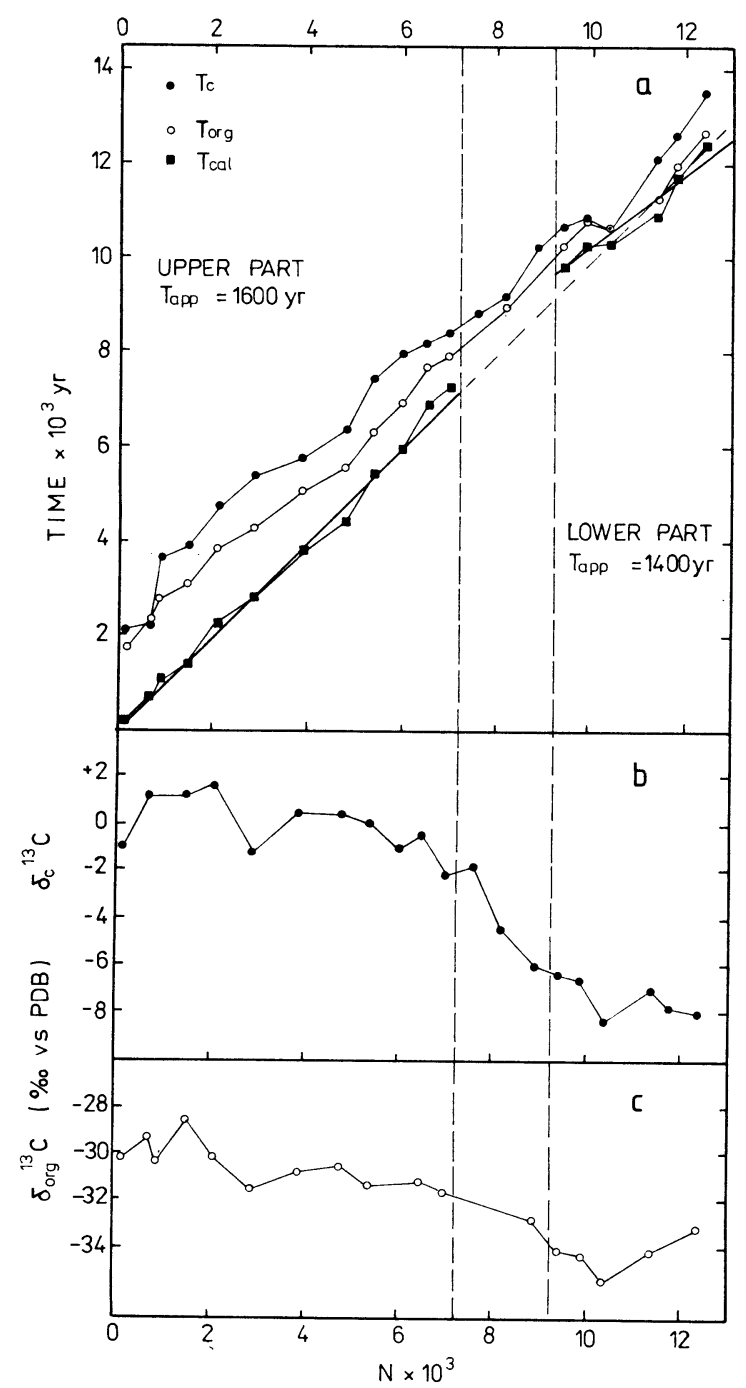

Fig $2 .{ }^{14} \mathrm{C}$ dates and $\delta^{13} \mathrm{C}$ values obtained on core $\mathrm{G} 0$ in function of varve number acc to $\mathrm{K}$ Więckowski (Ralska-Jasiewiczowa, Wicik \& Wiȩckowski, 1987)

$$
\mathrm{T}_{\text {cal }}=(-8 \pm 110)+(1.00 \pm 0.02) \mathrm{N}
$$

Correlation coefficient $\mathrm{r}=1.00$, the scatter of individual data points with respect to the least squares line is equal to $s=260 \mathrm{yr}$, ie, slightly exceeds the dating error. 


\section{Varve chronology}

A floating varve chronology, covering ca $10,000 \mathrm{yr}$, was established from cores G1 and G2. The surface of both cores was thoroughly cleaned and photographed; measurements of thickness of individual light (summer) and dark (winter) layers were performed on negatives using the apparatus designed for dendrochronological studies (Goslar, 1987). Apparatus accuracy is equal to $0.01 \mathrm{~mm}$; however, the boundaries between light and dark layers were identified with greater uncertainty, estimated to ca $0.05 \mathrm{~mm}$, and the resulting accuracy of layer thickness measurements is estimated to be ca $10 \%$.

Partial sequences obtained on cores G1 and G2 were combined into a floating varve chronology consisting of four segments which jointly cover 9682 couplets. The thicknesses of the light and dark layers were measured and treated separately, and the resulting chronology was constructed in three sequences, corresponding to light, dark, and total annual (light + dark) increments. There are three gaps in this sequence: the oldest gap is caused by a sandy layer, ca $0.5 \mathrm{~m}$ thick, overlying the oldest sequence with 294 couplets, two other gaps are represented by blue-gray massive layers (ca 5 and $15 \mathrm{~mm}$ thick), which occur in both cores. There are also several other gaps in the sequence obtained on cores G1 and G2; these gaps were filled with data available from core $\mathrm{G} 0$.

\section{Correlation of ${ }^{14} \mathrm{C}$ and varve chronologies}

Direct comparison of ${ }^{14} \mathrm{C}$ and varve chronologies of sediments of Gościasz Lake is complicated by the reservoir effect and resulting aging of ${ }^{14} \mathrm{C}$ dates of core $\mathrm{G} 0$. However, it is possible to gather the evidence provided by different cores shown in Figure 1 into a consistent chronologic picture: 1) ${ }^{14} \mathrm{C}$ dates were obtained on core $\mathrm{G} 0$, where two parts with approximately constant $\delta^{13} \mathrm{C}$ values may be distinguished; 2) peat layers found at the base of cores G86E and G86W provide the same dates (within limits of error), which may be used as estimates of the begining of lake marl sedimentation; 3) frozen cores taken by M Saarnisto from the uppermost unconsolidated sediment show lamination until the present; 4) available photographic documentation of core G0 permits exact matching of this core with cores G1 and $\mathrm{G} 2$, in spite of errors in varve number in the middle part of the core ( $c f$, Goslar, Pazdur \& Walanus, 1988).

\section{PERIODICITIES IN THE VARVE SEQUENCE}

Periodicities in the sequence of varve thickness obtained on cores G1 and G2 were sought for using running phase analysis, developed by Walanus (1988a). This method is based on Fourier analysis performed in a running manner, strictly for defined values of period, equal to $11,22,35$ and $200 \mathrm{yr}$, as suggested by results of other studies. The results indicate superimposed 11-and 22-yr cycles in the entire analyzed sequence, although, in some intervals, they cannot be regarded as significant, as the amplitude is rather low and the phase varies randomly. The 35- and 200-yr cycles occur over large parts of the laminated sequence, the last cycle is very distinct 


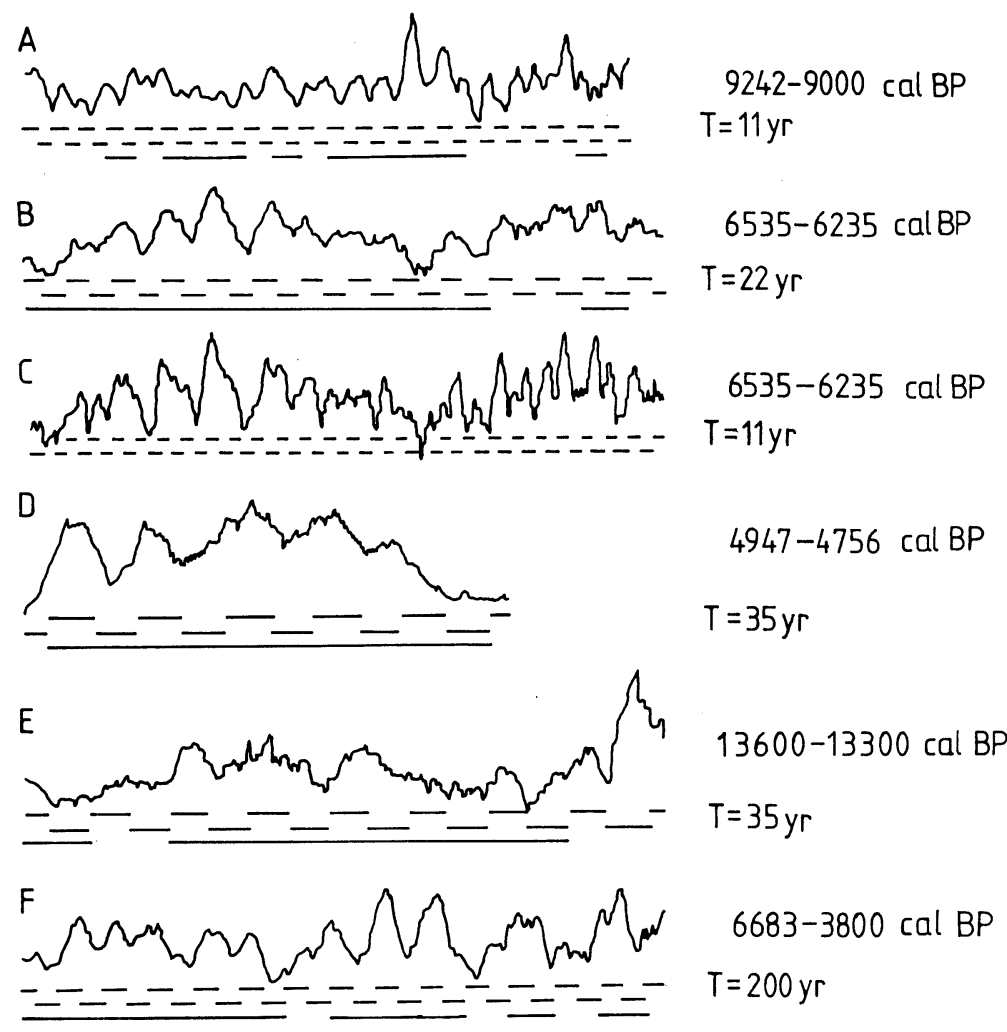

Fig 3. Examples of periodicities in sequence of varve thicknesses of core G1

from ca 7000 to $4500 \mathrm{cal} \mathrm{BP}$, with relatively high amplitude and stable phase (Walanus, 1988b). Illustrative examples are shown in Figure 3. The analysis of periodicities in this sequence is very difficult, as the data are noisy, and moreover, at least three sources of noise could be distinguished: 1) noise in the extraterrestrial signal; 2) noise connected with unknown environmental disturbances of the lake ecosystem; 3) noise introduced by coring. The influence of each of the quoted sources of error on the analyzed sequence of input data should be carefully studied and evaluated before attempting better understanding and interpretation of results of periodicity analysis in terms of environmental or extraterrestrial processes. We expect that the methods developed for analyzing tree-ring width data, and their results will be very important in studying varve sequences.

\section{FLUCTUATIONS OF WATER LEVEL IN GOŚCIẠZ LAKE}

Mass balance equations, describing the carbon and ${ }^{14} \mathrm{C}$ content of a lake, introduced by Broecker and Walton (1959), provide the relations between ${ }^{14} \mathrm{C}$ concentration in bicarbonates dissolved in lake water and the 
ratio of lake volume to its area, V/A. These equations were applied by Benson (1978) and Peng, Goddard and Broecker (1978) to derive corrected ${ }^{14} \mathrm{C}$ ages of carbonate sediments using estimated values of V/A ratio and other parameters incorporated in this model.

Laminated sediments of Gościąz Lake provide an independent absolute chronology and thus permit calculation of initial ${ }^{14} \mathrm{C}$ activity of bicarbonates from measured ${ }^{14} \mathrm{C}$ ages of carbonate fractions of lake marl. The equation of the Broecker-Walton model may be, in this case, rewritten to provide estimates of the ratio V/A, which may be interpreted as mean water depth of the lake. After some transformation, we get a simple relation between mean water depth, $\mathrm{H}$, and ${ }^{14} \mathrm{C}$ dilution factor, $\mathrm{q}_{\mathrm{L}}$, of lake carbonates at the moment of their sedimentation

$$
\mathrm{H}=\mathrm{Aq}_{\mathrm{L}}^{-1}-\mathrm{B},
$$

where $\mathrm{A}$ and $\mathrm{B}$ are combinations of model parameters, assumed constant during the entire history of the lake. Limnologic and geochemical considerations, accounting for data quoted by Benson (1978) and Peng, Goddard and Broecker (1978) lead to the estimate for the ratio of parameters A and B: $0.90<\mathrm{A} / \mathrm{B}<0.98$. Results of model calculations are shown in Figure 4 (Pazdur \& Starkel, 1988) as relative changes of lake water depth (with respect to $\mathrm{AD} 1830-1850$ level),

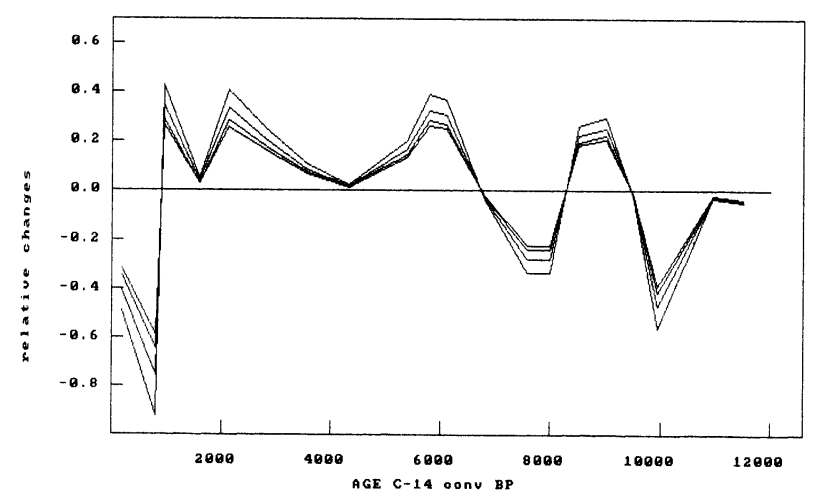

Fig 4. Fluctuations of lake level reconstructed from ${ }^{14} \mathrm{C}$ measurements of carbonate fraction of laminated sediment (according to Pazdur \& Starkel, 1988)

$$
\frac{\mathrm{H}}{\mathrm{H}_{0}}=\frac{(\mathrm{A} / \mathrm{B}) \mathrm{q}_{\mathrm{L}}^{-1}-1}{(\mathrm{~A} / \mathrm{B}) \mathrm{q}_{0}^{-1}-1}
$$

for selected values of the ratio $\mathrm{A} / \mathrm{B}=0.9,0.93,0.96,0.98$. Comparison of the obtained curve with paleohydrologic and paleoenvironmental data, gathered by Ralska-Jasiewiczowa and Starkel (1988) from studies of lakes, mires and rivers in Poland, shows reasonable coincidences. Moreover, a dis- 
tinct shift of rhythmic variations of mean water depth of Gościagz Lake, with respect to generalized paleohydrologic changes, is also visible. This shift in time may be explained by periodic floods of the lake basin and incising of the Ruda creek, draining this lake system, as well as changes of the Vistula River channel, which forms the basal level for Ruda creek and other small tributaries. These concepts will be verified in future studies of sediment sequences in the littoral area of Gościagz Lake and in the valley of Ruda creek.

\section{SUMMARY AND CONCLUSIONS}

Our results were obtained during the first two years of study of laminated sediments of Gościąz Lake, based on 3 cores, taken in 1985 and 1987. Measurements of varve thickness permit exact matching of the cores; good agreement between ${ }^{14} \mathrm{C}$ dates obtained on core $\mathrm{G} 0$ (calibrated after correcting for ${ }^{14} \mathrm{C}$ deficiency) and a varve chronology established on cores $\mathrm{G} 1$ and G2 suggests annual lamination in the lake. Additional evidence for annual lamination is provided by distinct periodical changes of varve thickness, especially by solar 11- and 22-yr cycles in the complete sequence, covering almost 10,000 yr. Definite proof of the annual character of lamination and exact dating of the floating varve chronology is expected from a correlation of varve thickness sequence with dendrochronologic records. Additional corings are necessary to extend this chronology to the recent three millennia where lamination is seriously disturbed. After completing this initial stage of the investigation with a reliable absolute varve chronology, the laminated sediments of Gościąz Lake will provide an important tool for studying geophysical and astrophysical processes during the Late Glacial and early Holocene, first of all through AMS dating of terrestrial macrofossils. We also expect that patterns of solar activity variations during this time will be reconstructed from the varve record, as was recently suggested by Bracewell (1988).

\section{ACKNOWLEDGMENT}

This study was supported by a grant from the Central Research Project CPBP 01. 06.

\section{REFERENCES}

Benson, L V, 1978, Fluctuation in the level of pluvial lake Lakontan during the last 40,000 years: Quaternary Research, v 9, p 300-318.

Bracewell, R N, 1988, Varves and solar cycles: Quaternary Jour Royal Astron Soc, v 29.

Broecker, W S and Walton, A, 1959, The geochemistry of ${ }^{14} \mathrm{C}$ in fresh-water systems: Geochim et Cosmochim Acta, v 16, p 15-38.

Geyh, M A, Merkt, J and Müller, H, 1971, Sediment-, Pollen-, und Isotopanalysen an jahrezeitlich geschichteten Ablagerungen in Zentralen Teil des Schleinsees: Archives Hydrobiol, v 69, p 366-399.

Goslar, T, 1987, Dendrochronological studies in the Gliwice Radiocarbon Laboratory, equipment, first results, in Eronen, M, ed, Dendrochronology around the Baltic: Acad Sci Fenn, Annales, ser AIII, Geol-Geog, no. 145, p 97-104.

Goslar, T, Pazdur, M F and Walanus, A, 1988, Chronology of lower part of annually laminated sediments of the Gościąz Lake: Zesz Nauk Pol Sląskiej, Geochronometria no. 5, p 11-22. 
O'Sullivan, P E, 1983, Annually-laminated lake sediments and the study of Quaternary environmental changes - a review: Quaternary Sci Rev, v 1, p 245-313.

Pazdur, A and Starkel, L, 1988, New approach to explanation of changes in the volume and water level of the Gościąz Lake: Zesz Nauk Pol slasskiej, Geochronometria no. 5, p 29-44.

Pazdur, M F, Awsiuk, R, Goslar, R, Pazdur, A, Walanus, A, Wicik, B and Więckowski, K, 1987, Calibrated radiocarbon chronology of annually laminated sediments from the Gościąz Lake: Zesz Nauk Pol Sląskiej, Geochronometria no. 4, p 69-83.

Pearson, G W, Pilcher, J R, Baillie, M G L, Corbett, D M and Qua, F, 1986, High-precision ${ }^{14} \mathrm{C}$ measurement of Irish oaks to show the natural ${ }^{14} \mathrm{C}$ variations from $\mathrm{AD} 1840-5210 \mathrm{BC}$, in Stuiver, $\mathrm{M}$ and Kra, RS, eds, Internatl ${ }^{14} \mathrm{C}$ conf, 12th, Proc: Radiocarbon, v 28, no. 2B, p 911-934.

Pearson, G W and Stuiver, M, 1986, High-precision calibration of the radiocarbon time scale, $500-2500 \mathrm{BC}$, in Stuiver, M, and $\mathrm{Kra}$, RS, eds, Internatl ${ }^{14} \mathrm{C}$ conf, 12th, Proc: Radiocarbon, v 28, no. 2B, p 839-862. Peng, T H, Goddard, J G and Broecker, W S, 1978, A direct comparison of ${ }^{14} \mathrm{C}$ and ${ }^{230} \mathrm{Th}$ ages
at Searles Lake, California: Quaternary Research, v 9, p 319-329.

Ralska-Jasiewiczowa, M and Starkel, L, 1988, Record of hydrological changes during the Holocene in the lake, mire and fluvial deposits of Poland: Folia Quaternaria, v 57, p 91-
127.

Ralska-Jasiewiczowa, M, Wicik, B and Więckowski, K, 1987, Lake Gościąz - a site of annually laminated sediments covering 12,000 years: Bull Polish Acad Sci, Earth Sci, v 35, p $127-$
137.

Saarnisto, M, 1986, Annually laminated lake sediments, in Berglund, B E, ed, Handbook of Holocene palaeoecology and palaeohydrology: New York, John Wiley \& Sons, p 343-370.

Stuiver, M, 1970, Long term ${ }^{14} \mathrm{C}$ variations, in Olsson, I U, ed, Radiocarbon variations and absolute chronology, Nobel symposium, 12th: New York, John Wiley \& Sons, p 197-213.

Stuiver, M, Kromer, B, Becker, B and Ferguson, C W, 1986, Radiocarbon age calibration back to 13,300 years BP and the ${ }^{14} \mathrm{C}$ age matching of the German oak and US bristlecone pine chronologies, in Stuiver, $\mathrm{M}$ and $\mathrm{Kra}, \mathrm{RS}$, eds, Internatl ${ }^{14} \mathrm{C}$ conf, 12th, Proc:
Radiocarbon, v 28, no. 2B, p 969-979.

Stuiver, $M$ and Pearson, G W, 1986, High-precision calibration of the radiocarbon time scale, $\mathrm{AD} 1950-500 \mathrm{BC}$, in Stuiver, $\mathrm{M}$, and $\mathrm{Kra}$, RS, eds, Internatl ${ }^{14} \mathrm{C}$ conf, 12th, Proc: Radiocarbon, v 28, no. 2B, p 805-838.

Tauber, H, 1970, The Scandinavian varve chronology and C14 dating, in Olsson, I U, ed, Radiocarbon variations and absolute chronology, Nobel symposium, 12th: New York, John Wiley \& Sons, p 173-196.

Tolonen, K, 1980, Comparison between radiocarbon and varve dating in lake Lampellonjärvi, South Finland: Boreas, v 9, p 11-19.

Walanus, A, 1988a, Running phase analysis and its application to cycle searching in long series of uncertain data: Zesz Nauk Pol Sląskiej, Geochronometria no. 5, p 45-51.

Lake: Zesz Nauk Pol Slasskiej, Geochronometria no. 5, p 53-62. 